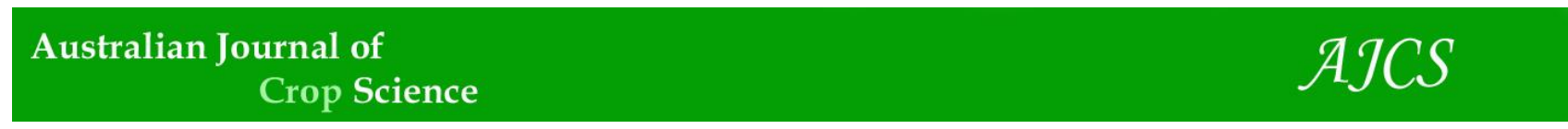

AJCS 13(12):2015-2021 (2019)

ISSN:1835-2707

doi: 10.21475/ajcs.19.13.12.p2021

\title{
Susceptibility of corn to stink bug (Dichelops melacanthus) and its management through seed treatment
}

\author{
Paulo Roberto da Silva ${ }^{1}$, Ademar Novais Istchuk ${ }^{2}$, Thomas E. Hunt ${ }^{3}$, Cristina Schetino Bastos* ${ }^{4}$, Jorge Braz \\ Torres ${ }^{5}$, Karolayne Lopes Campos ${ }^{4}$, Josemar Foresti ${ }^{2}$
}

${ }^{1}$ DuPont do Brasil S.A. Divisão Pioneer Sementes, Unidade de Pesquisa e Beneficiamento de Brasília - DF, Rod. DF 250, km 20 - Núcleo Rural Santos Dumont, lote 50, Cx. Postal 08283, 73310-970, Planaltina, DF, Brazil

${ }^{2}$ DuPont do Brasil S.A. Divisão Pioneer Sementes, Estação de Pesquisa de Toledo - PR, Estrada Toledo - Novo

Sobradinho, Sem Número, Linha Marreco, Cx. Postal 91, 85900-970, Toledo, PR, Brazil

${ }^{3}$ University of Nebraska Haskell Agricultural Laboratory, 57905866 Road, 68728, Concord, NE, EUA

${ }^{4}$ Universidade de Brasília (UnB), Faculdade de Agronomia e Medicina Veterinária (FAV), Campus Darcy Ribeiro, 70910-900, Brasília, DF, Brazil

${ }^{5}$ DEPA-Entomologia, Universidade Federal Rural de Pernambuco, Rua Dom Manoel de Medeiros, s/n - Dois Irmãos, 52171-900 Recife, PE, Brazil

*Corresponding author: cschetino@unb.br

Abstract

We determined the susceptibility of vegetative corn stages to Dichelops melacanthus damage, and how seed treatment can reduce damage and yield loss. Two field trials were carried out. In the first, corn plants were artificially infested with $D$. melacanthus male/female pairs at rate of 0.5 pair per plant at different vegetative stages and infestation periods lasting 7-28 days (V1-V3, V1-V5, V1-V7, V1-V9, V3-V5, V3-V7, V3-V9, V5-V7, V5-V9, and V7-V9), plus a control without infestation. In the second, corn plants were artificially infested at a rate of one male/female pair per plant at different vegetative stages and infestation periods (V1-V3, V1-V5, V1-V7, V3-V5, V3-V7 and V5-V7) and treated with two pesticide seed coatings: (i) fungicide [carbendazim + thiram (150 g i.a. per L and $350 \mathrm{~g}$ i.a. per L)] + insecticide [clothianidin ( $600 \mathrm{~g}$ i.a. per L)] or (ii) only fungicide (carbendazim + thiram), plus three controls without infestation and with only fungicide-treatment (V1-V7, V3-V7 and V5-V7). In both trials, plants were caged during the entire period in order to hold stink bugs in contact with plants and to avoid injury from other arthropods. The most stink bug susceptible corn growth periods were from V1-V5 and from V1-V7. Seed treatment with clothianidin at the rate of $3.5 \mathrm{~mL}$ per Kg during the most susceptible infestation periods increased yield gain of 37.8 to $61 \%$. Treatment with clothianidin during V1-V5 and V1-V7 caused $40 \%$ to $50 \%$ D. melacanthus adult mortality, respectively.

Keywords: Zea mays, Dichelops melacanthus, damage rating, clothianidin, vegetative stage corn development. Abbreviations: V1-V7_first to seventh leaf collar vegetative stage; DAE_days after emergence.

Introduction

The genus Dichelops is of Neotropical occurrence and contains three subgenera: Dichelops, Neodichelops and Prodichelops, which have 14 recognized species (Grazia, 1978 ) and another that was recently described (Klein et al., 2012). Although the range of stink bugs belonging to this genus is relatively restricted, the recent range expansion of other Pentatomidae species (Tindal and Fothergill, 2011; Martinson et al., 2016; Ciceoi et al., 2017) warns of the possible threat of their introduction and subsequent colonization of both cultivated (Olson et al., 2016; Tillman and Cottrell, 2016; Ciceoi et al., 2017) and wild hosts (Martinson et al., 2016). Dichelops melacanthus (Dallas) (Hemiptera: Pentatomidae), commonly known as green belly stink bug, currently occurs in Argentina, Bolivia, Brazil, Colombia, Paraguay, Peru, Uruguay and Venezuela (Dellapé et al., 2015).
Some authors describe $D$. melacanthus as a member of the subgenus Neodichelops (Grazia, 1978); while other authors include it in the subgenus Diceraeus (Rider, 2015). In spite of the variation in the nomenclature adopted, most of previous work treated it as D. melacanthus (Marques et al., 2007; Panizzi et al., 2007; Chocorosqui and Panizzi, 2008; RozaGomes et al., 2011; Silva et al., 2013; Torres et al., 2013; Crossariol Netto et al., 2015; Dellapé et al., 2015; Smaniotto and Panizzi, 2015; Bortolotto et al., 2016; Chiesa et al., 2016), and hence, this is the nomenclature that will be used throughout this manuscript.

Dichelops melacanthus is polyphagous, infesting 29 species of 10 botanical families, among which are crops such as rice, corn, soybean, sorghum, wheat, and various weeds (Panizzi et al., 2007; Chocorosqui and Panizzi, 2008; Smaniotto and Panizzi, 2015; Bortolotto et al., 2016). In legumes, such as 
soybean, infestation is concentrated in the reproductive stages (Silva et al., 2013); while in some Poaceae, such as corn and wheat, infestation and damage occurs in the seedling stage as a result of migrating adults from surrounding crop debris or other plants within the field (Torres et al., 2013; Smaniotto and Panizzi, 2015; Chiesa et al., 2016). Damage to seedling corn causes brown spots, leaf discoloration and twisting, reduced yield (Crossariol Netto et al., 2015), or plant death (Roza-Gomes et al., 2011; Torres et al., 2013).

In order to avoid yield loss in corn, neonicotinoid seed treatment is common (Martins et al., 2009; Brustolin et al., 2011; Crossariol-Neto et al., 2015; Chiesa et al., 2016). This insecticide group has been used alone or in combination with foliar insecticide treatment after crop emergence, or during crop desiccation and stalk destruction (Martins et al., 2009; Brustolin et al., 2011).

Previous studies have focused on evaluating the capacity of $D$. melacanthus to injure corn only during the seedling stage (Roza-Gomes et al., 2011; Torres et al., 2013), disregarding infestation and yield loss during other vegetative stages or different infestation periods. In addition, seed treatment targeting $D$. melacanthus has employed different active ingredients and has not documented yield protection (Martins et al., 2009; Brustolin et al., 2011). Therefore, this study aimed at evaluating the susceptibility of corn infested by $D$. melacanthus at different vegetative stages and for different infestation periods, and the effects of seed treatment on damage and yield.

\section{Results and Discussion}

\section{Vegetative stage corn susceptibility to $D$. melacanthus damage}

At the first evaluation, one day after insect removal, the greatest damage score was observed on plants infested at V1 (2 days after emergence - DAE) and V3 (9 DAE) (Figure 1). Damage scores decreased when corn plants were infested at later stages, V5 (16 DAE) and V7 (22 DAE) (Figure 1). At the second evaluation (ca., 7 days after insect removal), greater damage occurred to plants infested at V1 (2 DAE), and where infestation lasted until V7 (22 DAE) and V9 (29 DAE). The results were similar when plants were infested at V3 ( 9 DAE), and infestation lasted until V7 (22 DAE). Damage scores were lower for plants infested at V1, V5 and V7, but with infestation lasting for a maximum of seven days (infestation periods of V1-V3, V5-V7 and V7-V9). Damage scores for plants in the other treatments were intermediate between the highest and lowest values (Figure 1). At the third evaluation (ca., 14 days after insect removal), the most damaged plants were those infested in V1 and V3, with infestation lasting for 14-28 days (i.e., lasting until stage V7 or V9). The least damaged plants were infested very early (V1 or V3) with a seven day infestation period, or later (V5 or V7) with an infestation period of 14 days (Figure 1). Hence, the ability to recover from damage was increased when plants were infested in later vegetative stages or when infestation periods were shorter (ca., 7 days).

These results agree with those of Torres et al. (2013) when evaluating the injury caused by Euschistus heros (Fabr.) (Hemiptera: Pentatomidae) and D. melacanthus to corn infested 5 and 10 DAE. They found that at the first evaluation that plants infested at 5 DAE were more susceptible than plants infested at 10 DAE. However, at the second and third evaluations, no significant differences were observed between the two infestation stages. In addition, these authors held the insects in contact with plants for seven days, which agrees with the results found here when considering the same infestation period (i.e., V1-V3 and V3V5). Plants infested earlier in their development for only a short period of time (seven days or less) are less damaged than plants exposed to stink bugs for longer periods of time (more than seven days).

Corn seedling damage caused by $D$. furcatus, $D$. melacanthus, E. heros, and Nezara viridula (L) at stages V1 and $V 3$, with an infestation rate of one insect per plant for 14 days, resulted in stuck whorls and tillering (Roza-Gomes et al. 2011). Our study, examining the same infestation stages (V1 or V3) with an exposure time of 14-28 days, had similar results with reduced plant growth, dead heart and tillering. Previous work with a short infestation period (ca., 7 days) reported only yellow spots or discolored hearts (Torres et al. 2013), which indicates that plants were able to recover from injury when the infestation period was short. In view of that, the key period to manage $D$. melacanthus is during the beginning of seedling development when corn plants are between stages V1 or V3, and the control method should protect plants for at least 14 days.

\section{Clothianidin seed treatment effects to $D$. melacanthus mortality and injury to corn}

At the first evaluation, the most damaged plants occurred when they were infested at V1 for both insecticide treated and untreated plants. The only exception was for plants infested from V3-V5 and treated with clothianidin (Figure 2a), which also exhibited a high damage score. However, at the second evaluation, clothianidin treated plants that exhibited the highest damage score were those infested from V1-V3 and V1-V5. The highest damage scores for untreated plants occurred for plants infested from V1-V5 and from V1-V7 (Figure 2b). At the third evaluation, both clothianidin treated and untreated plants were most damaged when infestation occurred from V1-V5 and V1-V7. The remaining exposure periods resulted in lower scores irrespective of treatments (V1-V3, V3-V5, V3-V7 and V5-V7) (Figure 2c). Plants treated with clothianidin were less damaged that untreated plants when they were infested in V1 at all three evaluation times (Figure 2a-c).

The critical stages for both treated and untreated plants were when infestation occurred right after emergence (V1), and the infestation period lasted for 14-21 days, until V5 or V7. This pattern is similar to that found in the previous trial of vegetative stage susceptibility. Untreated plants had higher damage scores than treated plants at the same stages.

Seed treatment with clothianidin caused the highest $D$. melacanthus mortality during the critical infestation periods (i.e., from V1-V5 and V1-V7) (Figure 3). Mortality rates observed in the current study are in accordance with those observed in field trials for D. melacanthus when feeding on corn plants grown from imidacloprid and thiamethoxam treated seeds (between $23.2 \%$ to $42.7 \%$ ) (Chiesa et al., 2016). Further, our findings are in agreement with Crossariol Neto et al. (2015), where insecticidal seed treatment 


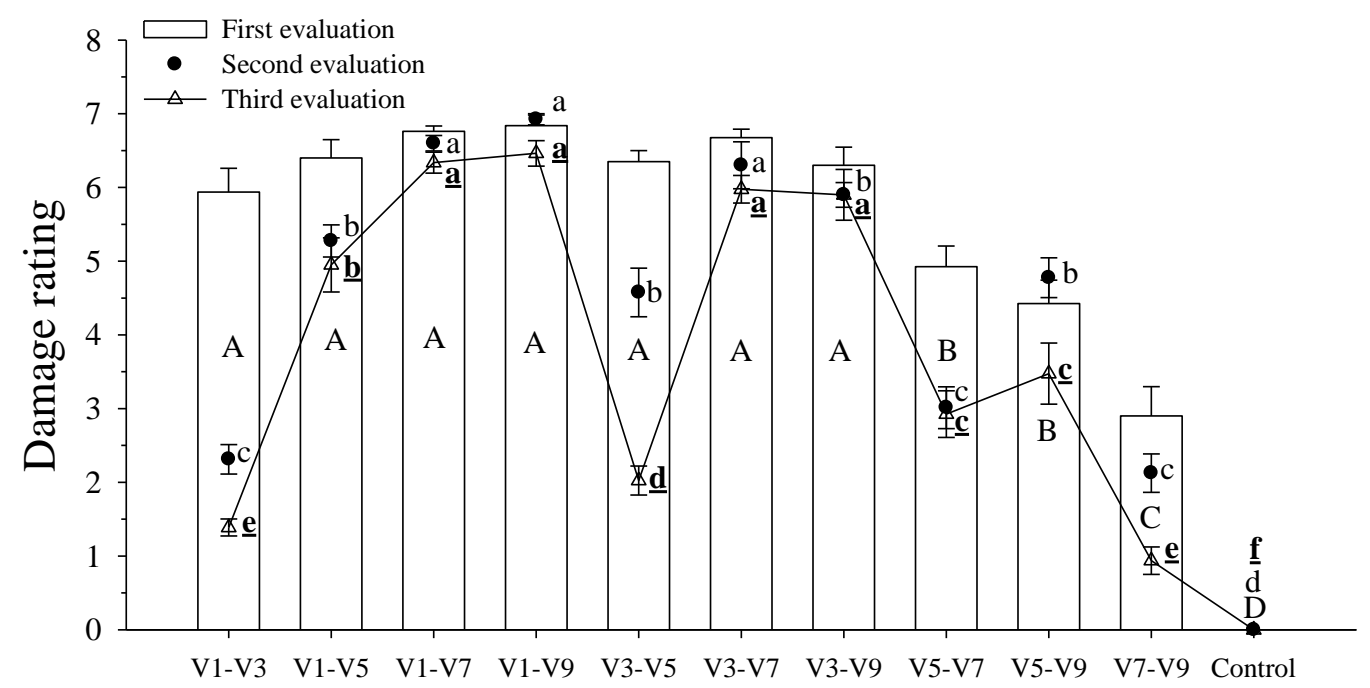

Fig 1. Dichelops melacanthus (Dallas) (Hemiptera: Pentatomidae) damage scores in corn (Zea mays) infested at different vegetative stages. Evaluations were performed one (first), seven (second) and 14 days (third) after the removal of insects. ${ }^{*}$ Means followed by the same letter, within each evaluation, do not differ by Scott-Knott test at $P<0.05$. Capital letters are associated with the first evaluation (bars), lower case letters are associated with the second evaluation (black dots), and lower case bold underlined letters are associated with the third evaluation (triangles).

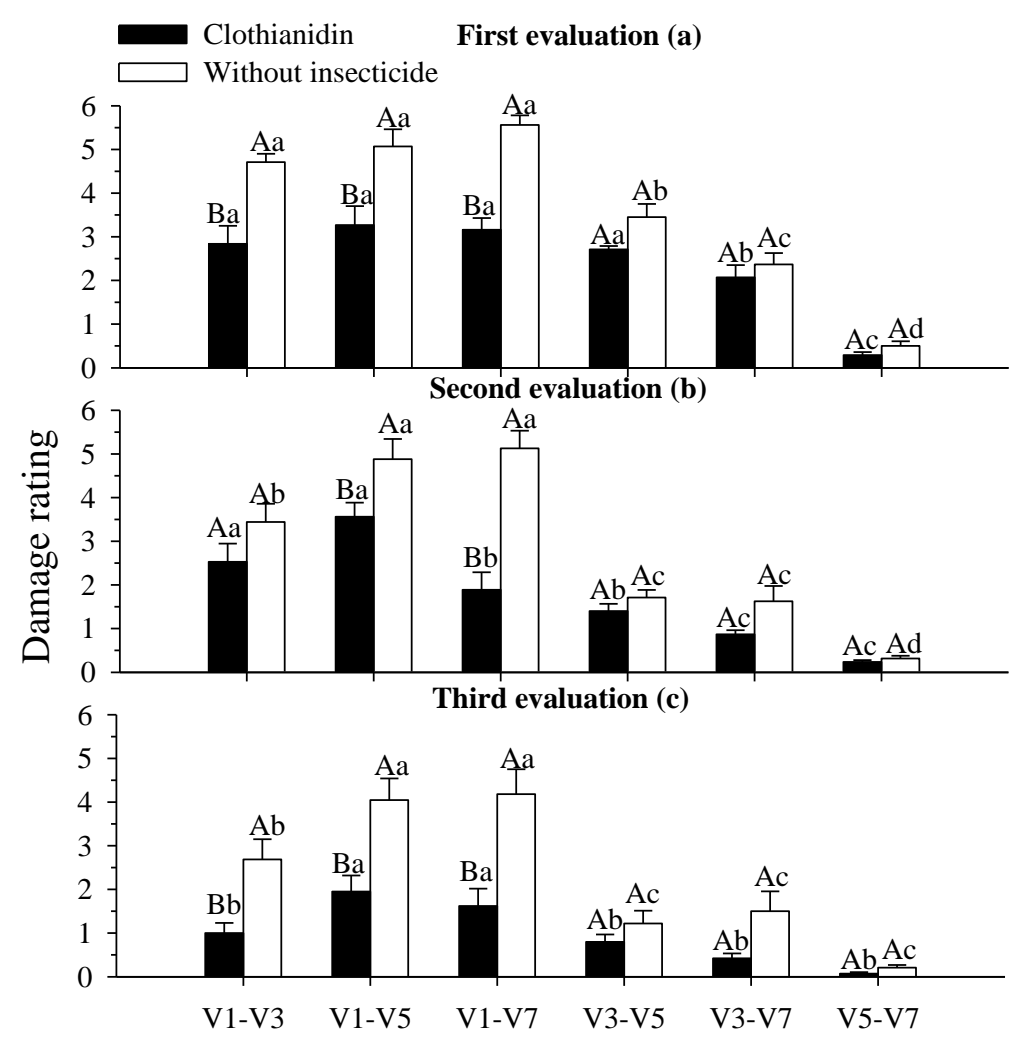

Fig 2. Dichelops melacanthus (Dallas) (Hemiptera: Pentatomidae) damage scores in corn (Zea mays) infested in different vegetative stages. Evaluations were performed one (first) (a), seven (second) (b), and 21 (third) (c) days after the removal of insects as a function of the presence or absence of clothianidin seed treatment. *Capital letters refer to treatment comparisons with and without insecticide within the same stage of corn development (Fisher's test); while, the lower case letters refer to comparisons of different stages of corn development within the same treatment with insecticide and without insecticide (Scott-Knott's test at $P<0.05)$. 


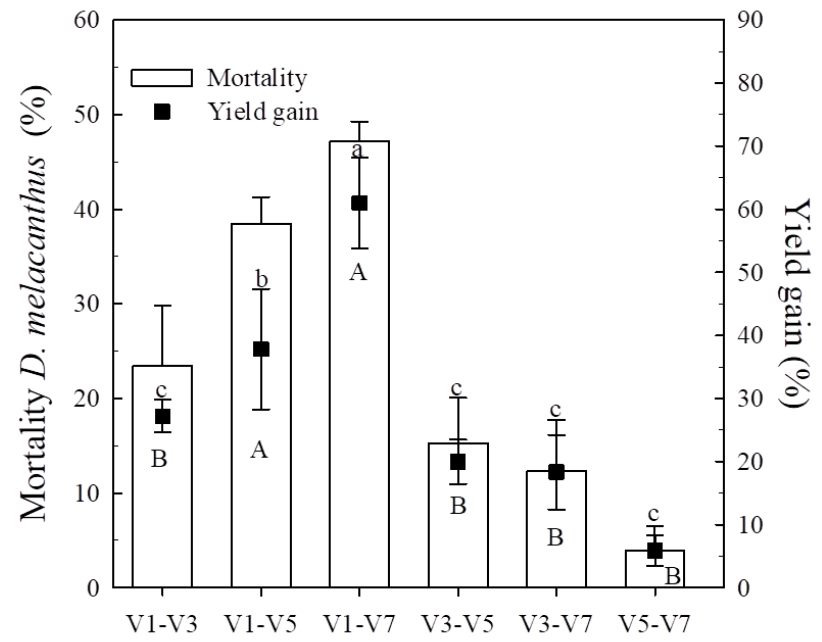

Fig 3. Percent mortality of Dichelops melacanthus adults (Dallas) (Hemiptera: Pentatomidae) (bars) and percent corn (Zea mays) yield gain (squares) in plants treated with clothianidin and carbendazim + thiran compared to plants treated only with carbendazim + thiran in different corn vegetative stages.*Means followed by the same letter, within each evaluation, do not differ by ScottKnott's test at $P<0.05$. Capital letters refer to comparisons between insect mortality (bars), and lower case letters refer to comparisons between yield gain (squares).

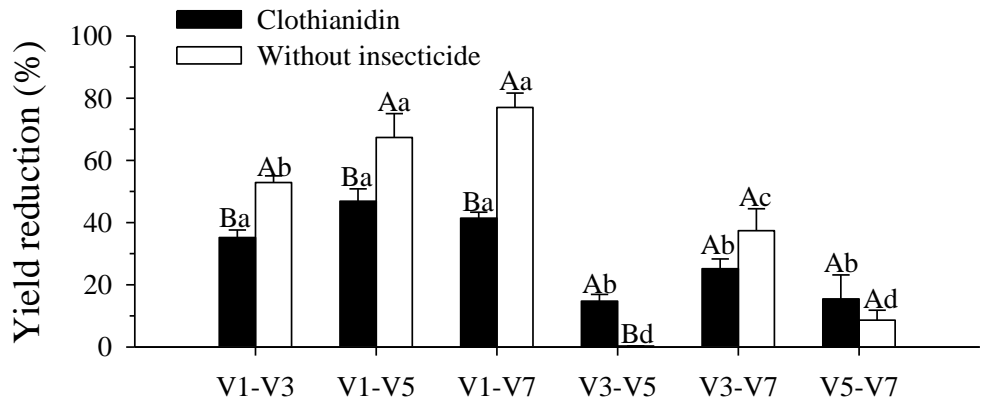

Fig 4. Percent corn (Zea mays) yield reduction of plants infested with Dichelops melacanthus (Dallas) (Hemiptera: Pentatomidae) in different vegetative stages compared to the non-infested corn plants. *Capital letters compare yield reduction of treatments with and without insecticide within the same stage of corn development (Fisher's test); the lower case letters compare yield reduction of different stages of corn development within the same seed treatment (Scott-Knott's test at $P<0.05$ ).

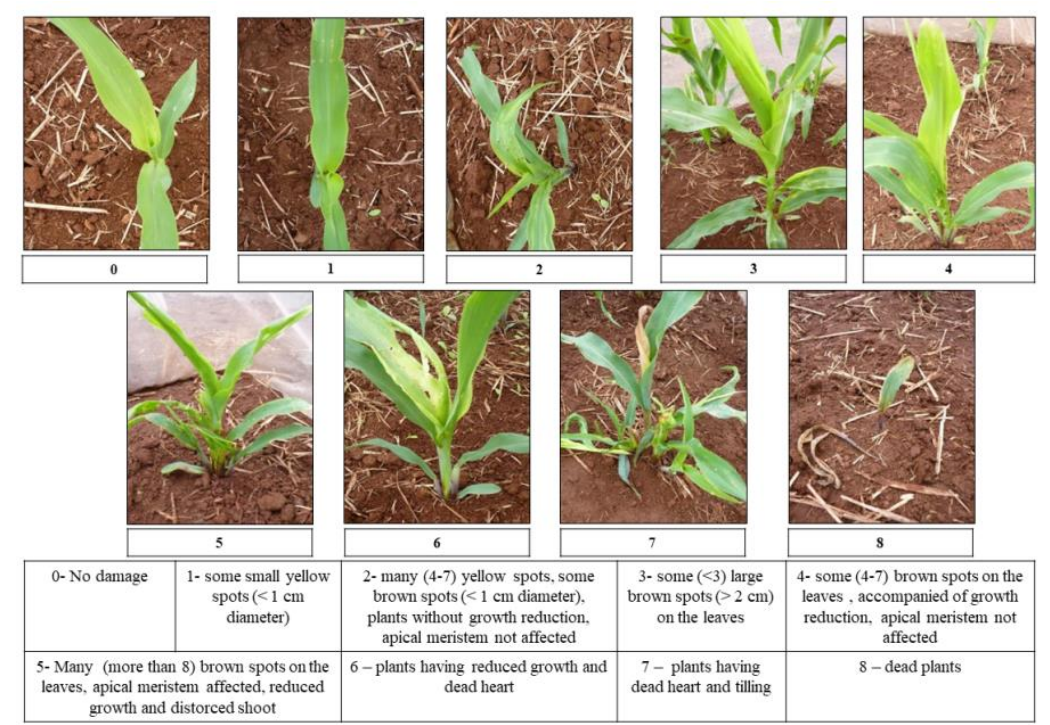

Fig 5. Representation and description of the damage score applied to corn plants (Zea mays) resulting from Dichelops melacanthus (Dallas) (Hemiptera: Pentatomidae) feeding. 
reduced the percentage of $D$. melacanthus infested corn plants. Likewise, in studies examining the control of $D$. melacanthus with the combination of insecticides (foliar spray and seed treatment), found that the percentage of infested plants was reduced most often when clothianidin and thiamethoxam seed treatments were used (Martins et al. 2009).

The highest mortality rates observed in our study (ca., 14-21 days) coincided with the period that the seed applied insecticide remained active. Translocation of clothianidin in corn seedlings from treated seeds exhibited high initial concentrations in shoot tissues, followed by a rapid decline within 20 days (16-22 days) (Alford and Krupke, 2017). However, even stink bug mortality rates of $40 \%$ to $50 \%$ did not circumvent plant injury during the critical stages (V1-V5 and V1-V7) of corn development. The remaining surviving insects and those replacing the dead insects were able to cause plant damage. It is crucial to determine if such infestation can cause yield loss.

The percentage of yield reduction, based on the noninfested plants, was significantly greater in clothianidin treated plants infested at V1, and not significantly different among others infested at V1, than those infested in V3 or V5 (Figure 4). The same pattern was observed for untreated plants, except that the reduction was significantly lower when the infestation occurred from V1-V3 than for V1-V5 or V1-V7. Infestation of untreated plants at the V1 resulted in greater yield loss than the clothianidin treated plants. The opposite was observed when plants were infested from V3V5. The yield reduction of clothianidin seed treated plants infested in V1 varied from $35 \%$ to $45 \%$, and for corresponding untreated plants varied from $53 \%$ to $77 \%$ (Figure 4).

The percentage of yield gain, calculated by comparing clothianidin treated and untreated seed plants, was 2.2410.4-fold greater for V1-V7 and 1.39-6.45-fold greater for V1-V5 compared to the remaining infestation periods. The infestation periods that most benefited from seed treatment were also the most critical periods for D. melacanthus infestation, V1-V5 and V1-V7, with yield gains of $40 \%$ and $60 \%$, respectively (Figure 3 ).

Previous studies do not recommend seed treatment for corn, based on the absence of yield gain compared to an untreated control (Chiesa et al., 2016). However, such studies were run under field conditions, and natural infestation resulted in an uncontrolled number of insects per plant, which reached up to seven insects per plant. In our study, the absence of seed treatment would result in considerable yield reduction, although seed treatment does not protect plants from late vegetative stage infestations. However, as observed in the current study, corn plants are less susceptible during late vegetative stages, and yield loss for untreated plants is 2.31- to 240-fold lower when plants are infested in V3 compared to V1. Considering the management of the pest under this situation, the joint use of seed treatments and foliar insecticide application, or other IPM measures, such as those that use edge-mediated movement to achieve better control (Tillman, 2010), planting dissociation in time or space with preferred legume crops (Panizzi et al., 2018), use of other trap crops (Silva et al., 2013) or use of genotypes with some degree of known resistance (Canassa et al., 2017) should allow effective control of this pest during most of the corn growing season.

\section{Materials and Methods}

\section{Vegetative stage susceptibility}

The trial was carried out in Santa Rosa - RS, Brazil, coordinates $27^{\circ} 50^{\prime} 37.2^{\prime \prime} \mathrm{S}$ and $54^{\circ} 28^{\prime} 11.7^{\prime \prime} \mathrm{W}$ at $330 \mathrm{~m}$ above sea level, from 30 Sept 2009 to 27 Jan 2010. The treatments were $D$. melacanthus infestation of corn plants at different corn stages (Abendroth et al. 2011) and periods: V1, V3, V5 and V7 (first, third, fifth and seventh leaf collar) for different infestation periods (7-28 days). Resulting infestation periods (treatments) were: V1-V3 (02-08 days after emergenceDAE), V1-V5 (02-15 DAE), V1-V7 (02-22 DAE), V1-V9 (02-29 DAE), V3-V5 (09-15 DAE), V3-V7 (09-22 DAE), V3-V9 (09-29 DAE), V5-V7 (16-22 DAE), V5-V9 (16-29 DAE), V7-V9 (23-29 $\mathrm{DAE})$, plus a control treatment without infestation. Plants were infested with $D$. melacanthus male/female pairs at a rate of 0.5 pair per plant. The treatments were arranged in a completely randomized block with four replications. The corn seed used was line P01 (Du Pont do Brasil S/A - Divisão Pioneer Sementes, Planaltina, DF, Brazil), which is used in a common corn hybrid composition cultivated for seed production. Plots were plowed once, harrowed twice, and fertilized with $400 \mathrm{t}$ per hectare of 05-20-20 (N: P: K). Corn seeds were manually planted, using two seeds per planting hole, $0.25 \times 0.25 \mathrm{~m}$ apart. Seedlings were enclosed by a voil cage $(1.0 \mathrm{~m}$ long $\times 1.5 \mathrm{~m}$ wide $\times 1.0 \mathrm{~m}$ high) right after emergence. Cages were supported by a system of ropes and wood poles. Plants were thinned to one plant per hole when they reached VE (emergence), and fertilized at V4 with 300 $\mathrm{Kg}$ of urea per hectare. Weeds were managed with one single application of atrazine $(500 \mathrm{~g}$ per $\mathrm{L}$, Atrazina Nortox 500 SC, Nortox S/A, Arapongas, PR) at the rate of $5 \mathrm{~L}$ per hectare right after sowing and before seedling emergence. Irrigation was provided with a sprinkler system right after sowing and weekly whenever rainfall did not occur for $>3 \mathrm{~d}$. Plants were infested with $D$. melacanthus adults collected in corn fields surrounding the trial area. The insects were kept within cages containing corn plants until use. Release of insects was not simultaneous for all treatments, but occurred when plants reached the appropriate vegetative stage as described above. Each cage received 10 male/female pairs, which resulted in an infestation rate of 0.5 pair per plant (1 bug per plant). Infestation periods varied from 7-28 days. Dead insects were replaced daily during the infestation periods to maintain the desired infestation level. At the end of the infestation periods, insects were removed and visual inspection of $D$. melacanthus damage was performed one, seven, and 14 days post insect removal. Evaluations followed a damage rating scale developed by Dupont Pioneer RMS (Research Management System) for stink bugs (plant damage scoring protocol), and scores varied from zero (no damage) to eight (dead plants) (Figure 5). Data from each evaluation time (one, seven and 14 days after insect removal) were submitted to one-way analysis of variance and mean comparison by Scott-Knott's test at $P<0.05$ using SAS software (SAS, 2002) and Genes (Cruz, 2013), respectively.

\section{Seed treatment trial}

The trial was conducted in Toledo, State of Paraná, Brazil (24 $40^{\circ} 18.5^{\prime \prime} \mathrm{S}, 53^{\circ} 45^{\prime} 30.3^{\prime \prime} \mathrm{W}$ and $555 \mathrm{~m}$ above sea level). 
Treatments consisted of the combination of six corn vegetative periods [V1-V3 (02-08 DAE); V1-V5 (02-15 DAE); V1-V7 (02-22 DAE); V3-V5 (09-15 DAE); V3-V7 (09-22 DAE); V5-V7 (16-22 DAE)] (Abendroth et al., 2011) $x$ two pesticide seed treatments: (i) fungicide + insecticide - carbendazim + thiram (150 g i.a. per $\mathrm{L}+350 \mathrm{~g}$ i.a. per $\mathrm{L}$ - Derosal Plus ${ }^{\circledR}$, Bayer S/A, Belford Roxo, RJ, Brazil) and clothianidin (600 g i.a. per $L$ - Poncho ${ }^{\circledR}$, Bayer S/A, Belford Roxo, RJ, Brazil); and (ii) fungicide Derosal Plus ${ }^{\circledR}$ (carbendazim + thiram). Three controls (no stink bug infestation) were included that were composed of insecticide untreated-plants corresponding to the V1-V7 (02-22 DAE), V3-V7 (9-22 DAE) and V5-V7 (16-22 DAE) periods, with only with the fungicide Derosal Plus ${ }^{\circledR}$ (carbendazim + thiram) seed treatment. There was a total of 15 treatments. Seeds were treated with $3 \mathrm{~mL}$ per $\mathrm{Kg}$ of carbendazim + thiram and with $3.5 \mathrm{~mL}$ per Kg of clothianidin. Treatments were arranged in a complete randomized block with five replications. The corn hybrid used was 30F53 (Du Pont do Brasil S/A - Divisão Pioneer Sementes, Planaltina, DF, Brazil), which is cultivated for seed production.

In order to infest plants simultaneously, sowing occurred on three different days: 28 Sep 2015, 04 Nov 2015 and 11 Nov 2015 (thus the three controls). Harvest of all plots occurred on 02 May 2015. Soil preparation, fertilization and weed control followed the same procedure described in the previous trial. Sowing was performed using one seed per hole spaced at $0.40 \times 0.416 \mathrm{~m}$ (plants $\mathrm{x}$ rows) for a total of nine plants per meter of row. Seedlings were enclosed by voil cages ( $1.2 \mathrm{~m}$ long $\times 1.25 \mathrm{~m}$ wide $\times 2.5 \mathrm{~m}$ high) right after emergence, and supported by ropes and wood poles as previously described.

Adult $D$. melacanthus were collected in the surrounding areas near Toledo, PR, Brazil, and were maintained until infestation as described for the vegetative stage susceptibility trial. Each cage was infested with nine $D$. melacanthus male/female pairs, except for the control cages, resulting in an infestation rate of one pair per plant. Insects remained in contact with the plants for 7-21 days, per described treatments. Dead insects were replaced every $3 \mathrm{~d}$ during the infestation period. At the end of the infestation period, insects were removed and evaluations were performed one, seven and 21 days after insect removal. The same damage rating scale described in Figure 5 was used in the evaluations.

At harvest, grain was manually separated from cobs, and the dry weight ( $13 \%$ humidity) was used for a per hectare yield estimation considering a plant population of 60,000 plants per hectare.

Mortality of $D$. melacanthus was corrected by the mortality in the untreated control treatments using the formula:

Mcorrected $(\%)=\frac{\text { (Mtreat-Mcontrol) }}{100-\text { Mcontrol }} \times 100$ (Püntener, 1981) where Mcorrected: mortality occurring in the treatment corrected by mortality that occurred in the control plots (\%); Mtreat: mortality in the treatment (\%); and Mcontrol: mortality in the control plot (\%).

Data of corrected mortality were subjected to one-way analysis of variance followed by mean comparisons performed by Scott-Knott's test at $P<0.05$ using the SAS system (SAS, 2002) and Genes (Cruz, 2013), respectively. Data from damage ratings, for each evaluation time, were submitted to two-way analysis of variance (corn stages $x$ seed treatment) and means comparisons were performed by
Scott-Knott's test at $P<0.05$ using the SAS system (SAS, 2002) and Genes (Cruz, 2013), respectively.

Yield was expressed as percentage of yield gain and yield reduction using the following formulae:

$\%$ yield gain $=\frac{\text { yield of infested plots treated with chlothianidin }+ \text { carbendazim }+ \text { thiram }}{\text { yield of infested plots treated only with carbendazim }+ \text { thiram }} \times 100$

$\%$ yield reduction

yield of infested plots treated with chlothianidin + carbendazim + thiram or only with carbendazim + thiram

yield of non - infested plots treated only with carbendazim + thiram $x 100$

The yield gain percentage was subjected to oneway analysis of variance and the yield loss percentage was subjected to two-way analysis of variance (corn stages $\mathrm{x}$ seed treatment), both followed by Scott-Knott test at $P<0.05$ used for means separation. The analyses were run in the SAS system (SAS, 2002) and Genes (Cruz, 2013).

\section{Conclusion}

Corn plants are more susceptible to $D$. melacanthus infestation in the seedling phase right after emergence, when plants are at stage V1 (first leaf collar) and the infestation period is maintained for at least 14 days, until stage V5 (fifth leaf collar) or stage V7 (seventh leaf collar). Seed treatment with clothianidin at the rate of $3.5 \mathrm{~mL}$ per $\mathrm{Kg}$ of seed resulted in $D$. melacanthus mortality during the critical stages (V1-V5 and V1-V7), avoiding damage and significantly reducing yield loss and increasing yield gain.

\section{Acknowledgements}

To Conselho Nacional de Desenvolvimento Científico e Tecnológico (CNPq) for supporting grants and to DuPont do Brasil, Divisão Pioneer Sementes for the logistic support that allowed to run the trials.

\section{References}

Abendroth L, Elmore RW, Boyer MJ, Marlay SK (2011) Corn growth and development. PMR 1009. Ames, lowa State University Extension.

Alford A, Krupke CH (2017) Translocation of the neonicotinoid seed treatment clothianidin in maize. Plos One. 12: e0173836.

Bortolotto OC, Mikamir AY, Bueno AF, Silva GV, Queiroz AP de (2016) Aspectos biológicos de Dichelops melacanthus em três temperaturas, alimentados com grãos imaturos de milho 2B688Hx e 2B688. Cienc Rural. 46: 254-259.

Brustolin C, Bianco R, Neves PMOJ (2011) Inseticidas em pré e pós-emergência do milho (Zea mays L.), associados ao tratamento de sementes, sobre Dichelops melacanthus (Dallas) (Hemiptera: Pentatomidae). Rev Bras Milho Sorgo. 10: 215-223.

Canassa VF, Baldin ELL, Bentivenha JPF, Pannuti LER, Lourenção AL (2017) Resistance to Dichelops melacanthus (Hemiptera: Pentatomidae) in soybean genotypes of different maturity groups. Bragantia. 76: 257-265.

Chiesa ACM, Sismeiro MN dos S, Pasini A, Roggia S (2016) Tratamento de sementes para manejo do percevejo barriga verde na cultura de soja e milho em sucessão. Pesqu Agropecu Bras. 51: 301-308. 
Chocorosqui VR, Panizzi AR (2008) Nymph and adult biology of Dichelops melacanthus (Dallas) (Heteroptera: Pentatomidae) feeding on cultivated and non-cultivated host plants. Neotrop Entomol. 37: 353-360.

Ciceoi R, Dumbrava M, Jerca IO, Pomohaci CM, Dobrin I (2017) Assessment of the damages on maize crop by the invasive stink bugs Halyomorpha halys (Stål, 1855) and Nezara viridula (Linnaeus, 1758) (Hemiptera: Pentatomidae). Acta Zool Bulg. Suppl. 9: 211-217.

Crossariol Netto J, Michelotto MD, Grigolli JFJ, Galli JA, Pirotta MZ, Busoli AC (2015) Damages caused by Dichelops melacanthus (Heteroptera: Pentatomidae) in conventional and transgenic corn hybrids. Biosci J. 31: 1092-1101.

Cruz CD (2013) GENES - a software package for analysis in experimental statistics and quantitative genetics. Acta Sci. 35: 271-276.

Dellapé G, Rider DA, Dellapé PM (2015) Notes on the distributions for Argentinian Pentatomidae (Heteroptera: Pentatomoidea), with new records in the country. Rev Bras Entomol. 5: 169-176.

Grazia J (1978) Revisão do gênero Dichelops Spinola, 1837 (Heteroptera, Pentatomidae, Pentatomini). Iheringia. 53: 3-119, 1978.

Klein JT, Barcellos A, Grazia J, Redaelli LR (2012) Contributions to the knowledge of Dichelops (Dichelops) with the description of a new species (Hemiptera: Heteroptera: Pentatomidae: Pentatominae: Carpocorini). Zootaxa. 3157: 61-68.

Marques FA, Wendler EP, Maia BHLNS, Ventura MU, ArrudaGatti C (2007) Identification of defensive compounds in metathoracic glands of adults of the stink bug Dichelops melacanthus (Hemiptera: Pentatomidae). J Brazil Chem Soc. 18: 1242-1246.

Martins GLM, Toscano LC, Tomquelski GV, Maruyama WI (2009) Controle químico do percevejo barriga-verde Dichelops melacanthus (Hemiptera: Pentatomidae) na cultura do milho. Arq Inst Biol. 76: 475-478.

Martinson HM, Bergmann EJ, Venugopal PD, Riley CB, Shrewsbury PM, Raupp MJ (2016) Invasive stink bug favors naive plants: testing the role of plant geographic origin in diverse, managed environments. Sci Rep. 6:32646.

Olson DM, Ruberson JR, Andow DA (2016) Relative longevity of adult Nezara viridula in field cages of cotton, peanut, and soybean. Entomol Exp Appl. 159: 30-36.
Panizzi AR, Lucini T, Possebom T (2018) Development of Dichelops furcatus (Hemiptera: Heteroptera: Pentatomidae) reared on spring cereal versus soybean. J Insect Sci. 18: 1-7.

Panizzi AR, Duo LSS, Bortolato NM, Siqueira F (2007) Nymph developmental time and survivorship, adult longevity, reproduction and body weight of Dichelops melacanthus (Dallas) feeding on natural and artificial diets. Rev Bras Entomol. 51: 484-488.

Püntener W (1981) Manual for field trials in plant protection. Basel, Ciba-Geigi Limited.

Rider DA (2015) Pentatomoidea home page. Disponível em: https://www.ndsu.edu/pubweb/ rider/Pentatomoidea/. Fargo: North Dakota State University, Department of Entomology. Acesso em: 28 agosto 2017.

Roza-Gomes MF, Salvadori JR, Pereira PRV da, Panizzi AR (2011) Injúrias de quatro espécies de percevejos pentatomídeos em plântulas de milho. Cienc Rural. 41: 1115-1119.

SAS (2002) Statistical analysis system: getting started with the SAS learning. Cary, SAS Institute.

Silva JJ, Ventura MU, Silva FAC, Panizzi AR (2013) Population dynamics of Dichelops melacanthus (Dallas) (Heteroptera: Pentatomidae) on host plants. Neotrop Entomol. 42: 141145.

Smaniotto LF, Panizzi AR (2015) Interactions of selected species of stink bugs (Hemiptera: Heteroptera: Pentatomidae) from leguminous crops with plants in the neotropics. Fla Entomol. 98:7-17.

Tillman, PG (2010) Composition and abundance of stink bugs (Heteroptera: Pentatomidae) in corn. Environ Entomol. 39: 1765-1774.

Tillman PG, Cottrell TE (2016) Stink bugs (Hemiptera: Pentatomidae) in pheromone baited traps near crop field edges in Georgia, USA. Fla Entomol. 99: 363-370.

Tindall KV, Fotergill K (2011) First records of Piezodorus guildinii in Missouri. Southwest Entomol. 36: 203-205.

Torres ABA, Oliveira NC de, Oliveira-Neto AM de, Guerreiro JC (2013) Injúrias causadas pelo ataque dos percevejos marrom e barriga verde durante o desenvolvimento inicial do milho. J Agron Sci. 2: 169-177. 